\title{
Regional differences in foraging of young-of-the- year Steller sea lions Eumetopias jubatus in Alaska: stable carbon and nitrogen isotope ratios in blood
}

\author{
Carolyn M. Kurle ${ }^{1,2, *}$, Carolyn J. Gudmundson ${ }^{1}$ \\ ${ }^{1}$ National Marine Mammal Laboratory, Alaska Fisheries Science Center, National Marine Fisheries Service, NOAA, \\ 7600 Sand Point Way NE, Seattle, Washington 98115, USA
}

${ }^{2}$ Present address: Ecology and Evolutionary Biology, University of California Santa Cruz, 100 Shaffer Road, Santa Cruz, California 95060, USA

\begin{abstract}
Stable nitrogen and carbon isotope ratios were measured from red blood cell (RBC) and serum components from 9 mo old Steller sea lions Eumetopias jubatus captured during February and March 2000 and 2001 from the Gulf of Alaska $\left(\mathrm{GOA}_{i}\right.$ Region 1, n = 11), the eastern Aleutian Islands (Region 3, $\mathrm{n}=5$ ), and the central Aleutian Islands (Region $4, \mathrm{n}=5$ ) to assess their foraging ecology. Isotope ratios from sea lions were compared with those from probable prey species and results were compared with those from a study demonstrating regional differences in the diets of juvenile and adult sea lions through the use of scat analysis. Discriminant analyses using the $\delta^{15} \mathrm{~N}$ and $\delta^{13} \mathrm{C}$ values of each blood component as the discriminant functions accurately classified sea lions to the appropriate foraging regions as predicted by a previous study employing scat analysis with an accuracy of $90 \%$ for serum and $95 \%$ for RBCs. The $\delta^{15} \mathrm{~N}$ values reflect a decrease in sea lion trophic position moving east to west that is probably driven by changes in sea lion diet. The $\delta^{13} \mathrm{C}$ values demonstrated clear distinctions between foraging locations that are likely driven by known geographic carbon isotope patterns observed in the GOA and along the Aleutian archipelago. Our data present further evidence that, in the marine environment, $\delta^{13} \mathrm{C}$ values do not covary with $\delta^{15} \mathrm{~N}$ values as a result of trophic enrichment, and are better determinants of foraging location than trophic position.
\end{abstract}

KEY WORDS: Steller sea lion $\cdot$ Eumetopias jubatus $\cdot$ Foraging ecology $\cdot$ Stable isotopes $\cdot$ Carbon $\cdot$ Nitrogen · Pinniped $\cdot$ Marine mammal

Resale or republication not permitted without written consent of the publisher

\section{INTRODUCTION}

Steller sea lions Eumetopias jubatus in North America range from the western Aleutian Islands east through the Gulf of Alaska (GOA) and south along the coast of British Columbia to central California. Based upon studies of mitochondrial DNA conducted in the late 1990s, the population was demonstrated to contain an eastern and a western stock, with the split occurring at $144^{\circ} \mathrm{W}$ at Cape Suckling in the GOA (Loughlin 1997). The western stock of Steller sea lions has declined sharply since the mid-1970s (Sease et al. 2001) and was declared endangered in 1997 (1972 US Endangered Species Act). Although the ultimate mechanisms for the decline are strongly debated, reductions in prey availability and subsequent alterations in sea lion diet are considered important contributing factors (Springer et al. 2003, Fritz \& Hinckley 2005, DeMaster et al. 2006). Changes in the prey field have been attributed to ecological regime shifts, climate change, commercial fishing, or a combination of factors (Loughlin \& York 2000). Consequently, effective 
management of Steller sea lions necessitates a greater understanding of their foraging ecology.

A common technique employed to estimate pinniped diets is the collection and examination of hard-part remains recovered from feces (Arim \& Naya 2003). However, this method can be problematic due to varied rates of digestion of prey hard parts (Arim \& Naya 2003). In addition, scats only offer an overview of an animal's most recent meals but do not provide integrated, long-term dietary information.

Pinniped foraging ecology has also been described using stable carbon $\left({ }^{13} \mathrm{C}:{ }^{12} \mathrm{C}\right)$ and nitrogen $\left({ }^{15} \mathrm{~N}:{ }^{14} \mathrm{~N}\right)$ isotope ratio analysis (Kurle \& Worthy 2001, 2002). Predictable enrichment of ${ }^{15} \mathrm{~N}$ with increasing trophic level allows estimation of an animal's relative trophic position (Vanderklift \& Ponsard 2003), whereas stable carbon isotopes can be strong indicators of an animal's habitat use and are valuable for estimating an animal's foraging region (Rubenstein \& Hobson 2004). Variations in carbon isotope ratios reflect sources of primary productivity which, in turn, reflect foraging area, making it possible to track movement and migration patterns between isotopically distinct geographic regions. Carbon isotope ratios of organisms in a marine trophic system are influenced by the phytoplankton and marine algae at the base of the food web which, in turn, are influenced primarily by phytoplankton size, geometry, and growth rate (Popp et al. 1998), the occurrence of phytoplankton blooms (Nakatsuka et al. 1992), the amount and types of primary productivity (Descolas-Gros \& Fontugne 1990), $\mathrm{CO}_{2}$ concentration and $\mathrm{CO}_{2}$ uptake mechanisms (Burkhardt et al. 1999, Tortell et al. 2000), and variations in aeration surrounding algae caused by turbulence (France 1995). These influences contribute to general geographic patterns for $\delta^{13} \mathrm{C}$ values in marine environments including decreasing $\delta^{13} \mathrm{C}$ values with increasing latitude in the northern hemisphere, higher $\delta^{13} \mathrm{C}$ values in northern oceans versus southern oceans, and higher $\delta^{13} \mathrm{C}$ values in benthic versus pelagic habitats and in nearshore versus offshore food webs (McConnaughey \& McRoy 1979, France 1995, Hobson 1999, 2005, Rubenstein \& Hobson 2004).

Stable carbon and nitrogen isotopes can also be used to estimate diet on the order of days to months as they reflect nutrients incorporated into particular tissues at time periods previous to collection that are dependent upon the metabolism and protein turnover of individual tissues (Kurle \& Worthy 2002). Blood is particularly desirable for use in isotope studies because its collection is minimally invasive and a routine component of animal research. Also, blood can be separated into constituents that, due to their varying protein and therefore isotopic turnover rates, can illustrate foraging data from different time periods (Kelly 2000). For example, stable carbon and nitrogen isotope ratios of serum are likely to reflect nutrients incorporated starting approximately 1 to 2 wk prior to collection, while those of red blood cells (RBCs) reflect dietary input beginning from as far back as 2 to 3 mo (Kurle 2002).

Despite its widespread use and acceptance as a technique for estimating wild animal trophic ecology, stable isotope technology can be problematic due to complications in interpreting isotopic data. Many studies would benefit from verification that could be achieved through the implementation of complementary methods or from controlled feeding experiments (see Gannes et al. 1997, Kelly 2000). Our study aimed to compare previous estimates of juvenile and adult Steller sea lion foraging ecology achieved through scat analysis with our own approximations obtained via stable carbon and nitrogen isotope analyses of blood components from 9 mo old sea lions and potential prey items. Time of weaning is unclear for Steller sea lions, but it is believed to occur gradually between 3 and 24 mo of age as they increasingly augment their mother's milk with solid food (Trites \& Porter 2002, Loughlin et al. 2003, Raum-Suryan et al. 2004). Therefore, the stable isotope values from the blood components of 9 mo old Steller sea lions reflect some combination of milk that reflects their mother's diet and their own opportunistic or intentional prey ingestion. The mean $\delta^{15} \mathrm{~N}$ values of blood components from mammals fed entirely on their mother's milk is consistently higher than those from their mother's blood constituents by $\sim 1.0 \%$, which is a fraction of a trophic level, whereas $\delta^{13} \mathrm{C}$ values remain the same between mother and offspring (Jenkins et al. 2001). Therefore, we hypothesized that foraging location and trophic level predicted by stable $\mathrm{C}$ and $\mathrm{N}$ isotope values of blood components of 9 mo old sea lions could reasonably be compared with foraging ecology estimates obtained from prey remains within fecal matter collected from juvenile and adult sea lions to determine if the isotope values indicate diet and foraging regions similar to those predicted by Sinclair \& Zeppelin (2002).

\section{MATERIALS AND METHODS}

Blood was drawn using serum collection tubes from young-of-the-year (9 mo old) male and female Steller sea lions captured in late February and early March 2000 and 2001 from several locations in Alaska (Fig. 1). Collection sites were grouped according to their placement within 3 of 4 different foraging regions previously classified by scat analyses (Sinclair \& Zeppelin 2002). Region 1 contained individuals sampled from Sea Otter and Long Islands in the Gulf of Alaska ( $\mathrm{n}=11$ ). Region 3, located in the eastern Aleutian Islands, contained individuals sampled from Akun, 
Tigalda, and Aiktak Islands $(\mathrm{n}=5)$. Region 4 , in the central Aleutian archipelago, contained individuals sampled from Seguam Island $(n=5)$. No sea lions were sampled in Region 2 due to logistic constraints.

We centrifuged blood samples for $5 \mathrm{~min}$ and harvested the separated serum and RBC components for analysis. Approximately $200 \mu \mathrm{l}$ of serum were pipetted from each sample and decanted onto pre-combusted glass fiber filter papers; the remaining RBCs were then removed onto filter papers. Papers were transferred to closed petri dishes, dried in an oven at $50^{\circ} \mathrm{C}$ for $24 \mathrm{~h}$, and stored in airtight vials at room temperature until analysis (see Hobson et al. 1997). Approximately 1.0 to $1.4 \mathrm{mg}$ of serum and 0.6 to $0.9 \mathrm{mg}$ of RBCs were removed from the filter papers with forceps and sealed in $5 \times 9 \mathrm{~mm}$ tin capsules. A negligible amount of filter paper may have been included with each sample, but isotopic analyses performed on the pre-combusted filter paper alone showed no measurable nitrogen or carbon, and so was not considered a contaminant. The blood components were analyzed using a Carlo Erba NA 1500 CHN Combustion Analyzer interfaced to a Finnigan Delta C mass spectrometer at the Stable Isotope/Soil Biology Laboratory, University of Georgia Institute of Ecology. The average precision for these data was $0.07 \%$ for nitrogen and $0.08 \%$ for carbon.

We used paired $t$-tests to determine differences in carbon and nitrogen isotope ratios between the RBC and serum blood components. We used single-factor analysis of variance (ANOVA) tests to determine differences in carbon and nitrogen isotope ratios of the 2 blood components between regions and Tukey's pair-

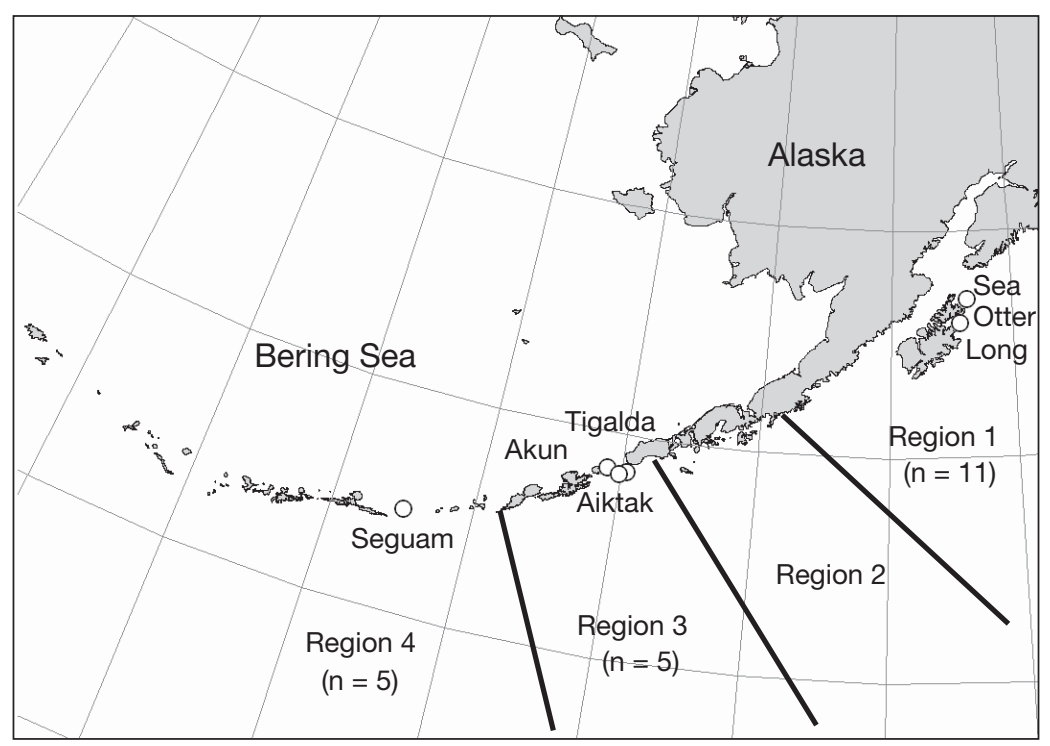

Fig. 1. Eumetopias jubatus. Sites in Alaska where blood components were collected from 9 mo old Steller sea lions. Foraging regions were previously determined through sea lion scat analysis by Sinclair \& Zeppelin (2002). $\mathrm{n}=$ number of samples wise comparison tests to determine which regions differed. Discriminant analysis was used to determine how well the isotope values from the sea lions predicted their inclusion into different winter-time geographic foraging regions as defined by Sinclair \& Zeppelin (2002). Discriminant functions were based on the carbon and nitrogen isotope ratios for each individual. The importance of the 2 variables in the discriminant analysis models were expressed on a scale of -4 to 5 for serum and -4 to 4 for RBCs (SYSTAT Version 10.2; SYSTAT Software). Significance was tested at the $\alpha=0.05$ level.

\section{RESULTS}

Mean nitrogen isotope ratios from RBCs were statistically significantly lower than those from serum from sea lions in Regions 1 and $3(t=-17.36, \mathrm{df}=10, \mathrm{p}<0.01$ and $t=-3.99, \mathrm{df}=4, \mathrm{p}=0.02$, respectively; Fig. 2); the trend was the same for individuals from Region 4 , but was not statistically significant $(t=-1.66, \mathrm{df}=4, \mathrm{p}=$ 0.17) (Fig. 2). The mean $\delta^{13} \mathrm{C}$ values from RBCs were statistically significantly higher than those from serum from individuals in Regions 1, 3, and $4(t=4.39, \mathrm{df}=10$, $\mathrm{p}<0.01, t=11.96, \mathrm{df}=4, \mathrm{p}<0.01$, and $t=10.70, \mathrm{df}=4$, $\mathrm{p}<0.01$, respectively; Fig. 2).

Mean nitrogen and carbon isotope ratios of RBCs from the sea lions sampled in Regions 1, 3, and 4 were statistically significantly different (ANOVAs, $F_{2,18}=$ 13.45, $\mathrm{p}<0.01$, nitrogen and $F_{2,18}=27.62, \mathrm{p}<0.01$, carbon; Fig. 2). The mean $\delta^{15} \mathrm{~N}$ values of the RBCs from Regions 1 and 3 were not different (Tukey's pairwise comparison test, $\mathrm{p}=$ 0.93), whereas the mean $\delta^{15} \mathrm{~N}$ values of RBCs from both regions were statistically significantly higher than those for RBCs from Region 4 (Tukey's pairwise comparison, $\mathrm{p}<0.01$ for both). The mean $\delta^{13} \mathrm{C}$ values of $\mathrm{RBCs}$ collected from sea lions in Regions 3 and 4 did not differ (Tukey's pairwise comparison, $p=0.5$ ), whereas the RBCs from sea lions from both regions had statistically significantly lower mean $\delta^{13} \mathrm{C}$ values than those from sea lions in Region 1 (Tukey's pairwise comparison, $\mathrm{p}<0.01$ for both; Fig. 2).

Mean nitrogen and carbon isotope ratios from serum from the sea lions sampled in Regions 1, 3, and 4 were statistically significantly different (ANOVAs, $F_{2,18}=14.12, \mathrm{p}<0.01$, nitrogen and $F_{2,18}=90.81, \mathrm{p}<0.01$, carbon; Fig. 2). The mean $\delta^{15} \mathrm{~N}$ values from the 


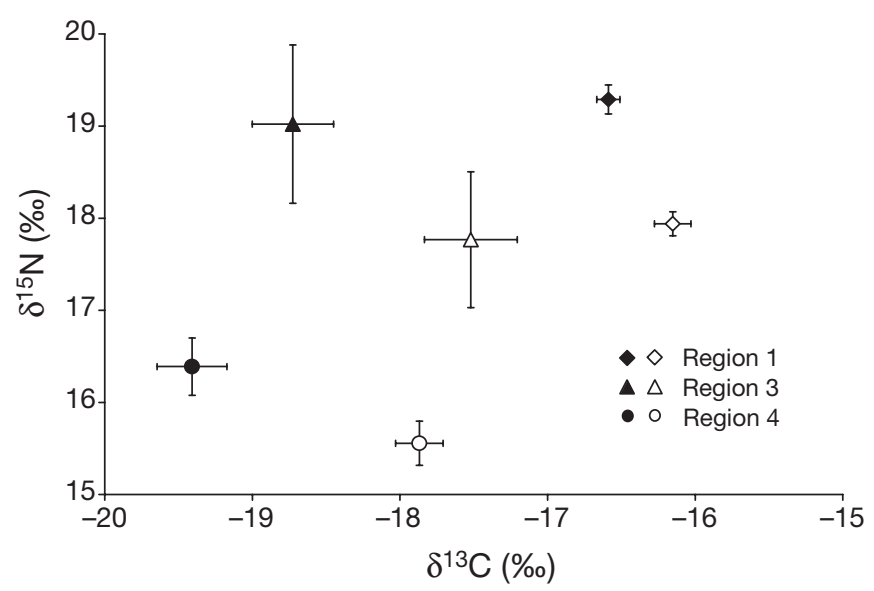

Fig. 2. Eumetopias jubatus. Mean $( \pm \mathrm{SE}) \delta^{15} \mathrm{~N}$ and $\delta^{13} \mathrm{C}$ of red blood cells (open symbols) and serum (filled symbols) from 9 mo old Steller sea lions collected in late February to early March 2000 and 2001 in Alaska from 3 winter foraging regions defined through scat analysis by Sinclair \& Zeppelin (2002)

serum collected from sea lions in Regions 1 and 3 did not differ (Tukey's pairwise comparison, $\mathrm{p}=0.88$ ), whereas the mean $\delta^{15} \mathrm{~N}$ values from both regions were statistically significantly higher than the values from Region 4 (Tukey's pairwise comparison, $\mathrm{p}<0.01$ for both). The mean $\delta^{13} \mathrm{C}$ values of serum collected from sea lions from all regions were statistically significantly different from one another; Region 1 was the highest followed by Region 3 and then Region 4 (Tukey's pairwise comparison, Regions 1 and 3: $\mathrm{p}<0.01$; Regions 1 and 4: $\mathrm{p}<0.01$; Regions 3 and $4: \mathrm{p}=0.05$; Fig. 2).

Discriminant analysis is a statistical tool that allows classification of observations into groups and determines the success of that classification. The jackknifed classification matrix from the discriminant analysis using the classification factors derived from the stable carbon and nitrogen isotope ratios from the RBC samples assigned 20 of the 21 (95\%) sea lions correctly to the predetermined foraging regions outlined in Sinclair \& Zeppelin (2002) and the separations were statistically significant (Pillai's trace, $F=22.33, \mathrm{df}=4$, $\mathrm{p}<0.01$; Fig. 3a). The jack-knifed classification matrix from the discriminant analysis using the classification factors derived from the stable carbon and nitrogen isotope ratios from the serum samples assigned 19 of $21(90 \%)$ sea lions to the correct foraging region and the separations were also statistically significant (Pillai's trace, $F=18.71, \mathrm{df}=4, \mathrm{p}<0.01$; Fig. $3 \mathrm{~b}$ ). The proportion of the total variance explained by the 2 factors used to create the classification matrix in each analysis was $100 \%$. All individuals incorrectly assigned came from Region 3 and were misclassified into Region 4.

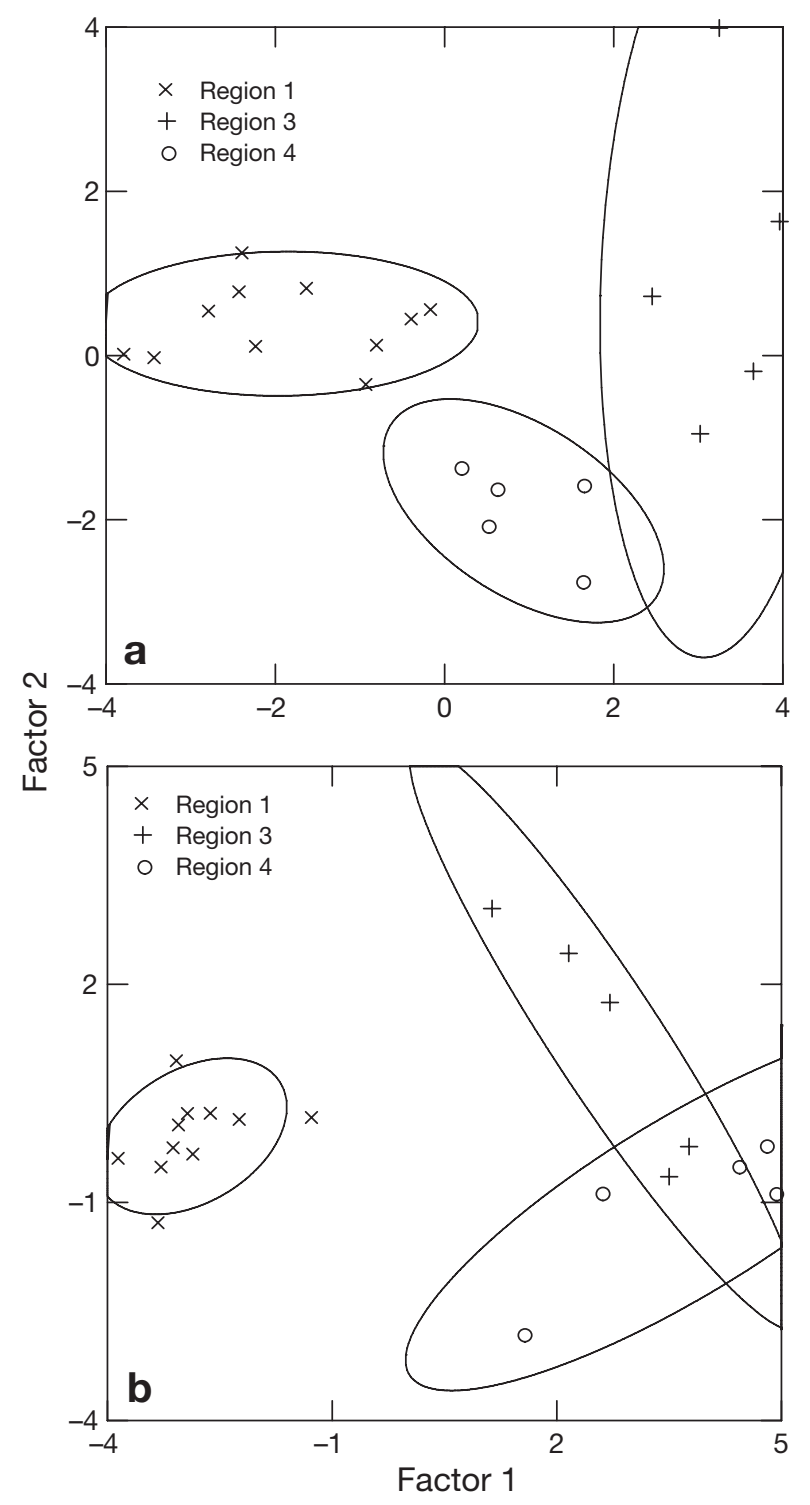

Fig. 3. Eumetopias jubatus. Position of 9 mo old Steller sea lions and their significant separations into 3 foraging regions based upon $\delta^{15} \mathrm{~N}$ and $\delta^{13} \mathrm{C}$ values of their (a) red blood cells and (b) serum. Canonical discriminant functions standardized by within-variances comprise Factors 1 and 2. Factor 1 ranges from (a) -1.9 for carbon to 1.5 for nitrogen and (b) -1.1 for carbon to 0.3 for nitrogen; Factor 2 ranges from (a) -0.3 for carbon and 1.2 for nitrogen and (b) -0.3 for carbon and 1.1 for nitrogen. Ellipses represent $95 \%$ confidence regions around each cluster of points

\section{DISCUSSION}

Sinclair \& Zeppelin (2002) defined 4 foraging regions occupied by Steller sea lions from the western stock in Alaska in both summer and winter based upon their diet composition as determined from scat collections 
representing juvenile and adult sea lions. Our data were collected in winter, so we compared our stable isotope values with their winter foraging patterns and found that the stable nitrogen and carbon isotope ratios from blood components of 9 mo old Steller sea lions predicted the same pattern in foraging regions as that shown by Sinclair \& Zeppelin (2002).

The clear delineation between foraging regions demonstrated by the stable isotope data is primarily due to 2 factors. First, the variations in the mean $\delta^{15} \mathrm{~N}$ values from the blood components of sea lions among foraging regions were probably due to differences in primary prey consumed either by their mothers or by the 9 mo old sea lions within each area. The mean $\delta^{15} \mathrm{~N}$ values for the RBC and serum components from sea lions in Region 1 were $17.9 \%$ o $( \pm 0.1 \mathrm{SE})$ and $19.3 \%$ ( $\pm 0.2 \mathrm{SE})$, respectively (Table 1$)$. The nitrogen isotope fractionation factors between prey and predator for $\mathrm{RBC}$ and serum components from northern fur seals Callorhinus ursinus are +4.1 and $+5.2 \%$, respectively (Kurle 2002). Assuming similar conversions for Steller sea lions, the $\delta^{15} \mathrm{~N}$ value of all prey consumed by sea lions in Region 1 should average $14.0 \%$ (17.9 $4.1 \%$ o $13.8 \%$ and $19.3-5.2 \%$ o $=14.1 \%$ ). The $\delta^{15} \mathrm{~N}$ values from sea lion blood components in Region 3 were only slightly less (and not statistically significantly so) than those in Region 1, suggesting that young-of-theyear sea lions or their mothers forage at the same trophic level in both regions. Following the application of fractionation factors for the blood components, we calculated the $\delta^{15} \mathrm{~N}$ value for the sea lion prey in Region 4 as $\sim 11.3 \%$. Because the mean $\delta^{15} \mathrm{~N}$ values from RBCs and serum from sea lions in Region 4 were lower (15.6 and 16.4\%, respectively; Table 1) than those from individuals in Regions 1 and 3, we conclude that the 9 mo old sea lions or their mothers in Region 4 were foraging at $\sim 1$ trophic level lower than their counterparts in other regions.

The distinct differences among foraging regions demonstrated from the scat analysis in Sinclair \& Zeppelin (2002) were driven by variations in prey consumption by sea lions from east to west. They showed that, in winter, sea lion diet was defined primarily by

Table 1. Eumetopias jubatus. Mean $( \pm \mathrm{SE}) \delta^{15} \mathrm{~N}$ and $\delta^{13} \mathrm{C}(\%)$ of red blood cells (RBC) and serum from 9 mo old Steller sea lions collected in late February to early March 2000 and 2001 in Alaska from 3 wintertime foraging regions defined through scat analysis by Sinclair \& Zeppelin (2002)

\begin{tabular}{|lccccc|}
\hline \multirow{2}{*}{ Region } & \multicolumn{2}{c}{ RBC } & & \multicolumn{2}{c|}{ Serum } \\
\cline { 2 - 5 } & $\delta^{15} \mathrm{~N}$ values & $\delta^{13} \mathrm{C}$ values & & $\delta^{15} \mathrm{~N}$ values & $\delta^{13} \mathrm{C}$ values \\
\hline $1(\mathrm{n}=11)$ & $17.9 \pm 0.1$ & $-16.2 \pm 0.1$ & & $19.3 \pm 0.2$ & $-16.6 \pm 0.1$ \\
$3(\mathrm{n}=5)$ & $17.8 \pm 0.7$ & $-17.5 \pm 0.3$ & & $19.0 \pm 0.9$ & $-18.7 \pm 0.3$ \\
$4(\mathrm{n}=5)$ & $15.6 \pm 0.2$ & $-17.9 \pm 0.2$ & & $16.4 \pm 0.3$ & $-19.4 \pm 0.2$ \\
\hline
\end{tabular}

walleye pollock Theragra chalcogramma in the east and Atka mackerel Pleurogrammus monopterygius and cephalopods in the west. The $\delta^{15} \mathrm{~N}$ values for sea lion blood components demonstrate that 9 mo old sea lions in the east were ingesting food either in the form of their mother's milk or prey that were at a higher trophic level than that ingested by their counterparts farther west. Stable isotope values represent an amalgamation of all prey ingested and are less appropriate for delineating between prey that have closely matched isotope values and more useful for illustrating trends in trophic position that can be compared with the fecal material data. Sub-adult (3 to $4 \mathrm{yr}$ old) and adult (5+ yr old) pollock and Atka mackerel are thought to be the most common age groups of fishes ingested in winter by Steller sea lions (Zeppelin et al. $2004)$. The mean $( \pm \mathrm{SE}) \delta^{15} \mathrm{~N}$ value for 3 to $4 \mathrm{yr}$ old pollock collected in summer 1997 from the Bering Sea is $16.3 \pm 0.3 \%$ (Kurle \& Worthy 2001). In contrast, the mean $( \pm \mathrm{SE}) \delta^{15} \mathrm{~N}$ values for 4 yr old Atka mackerel and from small and medium squid (Gonatopsis borealis and Berryteuthis magister) are $10.7 \pm 0.3$ and $11.1 \pm 0.2$ to $11.4 \pm 0.2 \%$, respectively (all prey collected in summer 1997 from the Bering Sea; Kurle \& Worthy 2001). It can reasonably be expected that the trend in decreasing trophic level exhibited by the decreasing $\delta^{15} \mathrm{~N}$ values from east to west in sea lion blood components can be explained by the change in diet from pollock to Atka mackerel and squid observed in the scat analyses.

The second factor contributing to the accurate separation of sea lions into the 3 foraging regions is the natural variation that occurs in $\delta^{13} \mathrm{C}$ values among geographic locations, including within marine environments (Kelly 2000, Rubenstein \& Hobson 2004), which allows tracking movement and migration patterns between isotopically distinct geographic regions. One such geographic pattern is that of decreasing $\delta^{13} \mathrm{C}$ values with longitude from east to west from the GOA across the eastern Aleutian archipelago. Copepods, yellowfin sole Limanda aspera, squid Berryteuthis spp., and adult Pacific cod Gadus macrocephalus, walleye pollock, and herring Clupea pallasi sampled in the mid-1990s (Hirons et al. 1998) and in winter 2000 (C. M. Kurle et al. unpubl.) have consistently higher $\delta^{13} \mathrm{C}$ values in the GOA than individuals from the Bering Sea. This pattern is also reflected farther west along the Aleutian archipelago. Eleven marine species collected from the Bering Sea off the central Aleutian Islands (near Adak and Amchitka Islands) had higher mean $\delta^{13} \mathrm{C}$ values than the same species sampled off the western Aleutians (near Shemya and Alaid/Nizki Islands) (Duggins et al. 
1989, Simenstad et al. 1993). In addition, rock greenling Hexagrammos lagocephalus and kelp Alaria fistulosa sampled from the Bering Sea demonstrated higher $\delta^{13} \mathrm{C}$ values off the central Aleutian Islands (near Adak and Amchitka Islands) than in the far west (near Shemya and Attu Islands) (Reisewitz 2002). It is likely that regionalized phenomena contributing to this longitudinal pattern influenced the spatial patterns observed in the carbon isotope ratios from the blood components of sea lions in this study. This may reflect the patterns of the mothers or young-of-the-year, depending on whether the 9 mo old sea lions are still fully dependent on milk, supplement milk with opportunistic prey ingestion, or forage independently.

Our data strongly indicate that, in marine systems, variations in oceanographic processes that influence carbon acquisition at the primary production level among regions strongly affect $\delta^{13} \mathrm{C}$ values of consumers, making them more useful for determining habitat use than trophic position. However, there is some evidence of and a call for more studies to determine whether, in marine systems, $\delta^{15} \mathrm{~N}$ and $\delta^{13} \mathrm{C}$ values significantly covary as a result of strong trophic enrichment in both ${ }^{15} \mathrm{~N}$ and ${ }^{13} \mathrm{C}$ (see review by Kelly 2000), with a value of $1 \%$ as the hypothesized enrichment factor between trophic levels for $\delta^{13} \mathrm{C}$ (Rau et al. 1983). Our data from sea lions and the data presented above from other marine organisms collected in Alaskan waters do not support a covarying trophic enrichment in $\delta^{15} \mathrm{~N}$ and $\delta^{13} \mathrm{C}$ values. If the patterns observed in the $\delta^{13} \mathrm{C}$ values obtained from the blood components of the sea lions were a reflection of an increase in trophic position, then the expected $\delta^{15} \mathrm{~N}$ values from the marine organisms and the sea lions among the regions should reflect a corresponding difference. The mean differences in $\delta^{13} \mathrm{C}$ values for the marine organisms between regions were from 0.6 to $2.1 \%$, indicating that species in the GOA hypothetically forage at 1 to 2 level trophic levels above those in the Bering Sea. If true, one would expect to see a corresponding increase in the $\delta^{15} \mathrm{~N}$ values of at least 4 to $5 \%$, which is the accepted amount of increase expected for an increase of 1 trophic level (Kurle 2002). The variations in the $\delta^{15} \mathrm{~N}$ values from the various marine organisms between geographic regions were between 0.3 and $1.9 \%$ (Hirons et al. 1998, C. M. Kurle et al. unpubl.), which are not sufficient to indicate a trophic separation. In addition, sea lions in Regions 1 and 3 have $\delta^{13} \mathrm{C}$ values that differed by $\sim 2 \%$, which translates into a hypothetical trophic separation of 2 levels. However, both the $\delta^{15} \mathrm{~N}$ and scat data demonstrate that sea lions in the 2 regions forage at the same trophic level. Therefore, we contend that stable carbon isotope signatures are better determinants of foraging location than trophic position.
Isotope ratios of different tissues from the same individual are rarely uniform, even when it is held on constant diets in captivity (Kurle 2002, Vanderklift \& Ponsard 2003). Discrepancies in the carbon and nitrogen isotope ratios between the RBCs and serum may be partially attributable to differences in the primary proteins and subsequent amino acids present in the different blood components, as $\delta^{13} \mathrm{C}$ and $\delta^{15} \mathrm{~N}$ values of individual amino acids encompass a wide range (Fantle et al. 1999). In addition, differences in the amount of lipid content present in serum versus RBCs may have contributed to the lower mean $\delta^{13} \mathrm{C}$ values in the serum components. Total lipids are higher in serum than in RBCs because serum albumin is the major carrier of fatty acids in the blood (Nelson 1970, 1971). Lipids are known to have proportionally less ${ }^{13} \mathrm{C}$ than proteins (see Kelly 2000), which leads to lower $\delta^{13} \mathrm{C}$ values (see also Kurle 2002). Alternatively, protein turnover and therefore isotopic turnover varies with tissue type and the $\delta^{15} \mathrm{~N}$ and $\delta^{13} \mathrm{C}$ values from RBCs are thought to indicate prey incorporated up to 2-3 mo prior to blood collection, while those from serum are thought to illustrate dietary items incorporated as recently as 1 to $2 \mathrm{wk}$ prior to collection (Kurle 2002). Therefore, differences in the isotope ratios between the 2 blood components may indicate temporal variations in sea lion foraging. To assess this, it is important to first rule out the influences of the differing amino acid and lipid components present in each of the blood constituents. Kurle (2002) demonstrated that the mean $\delta^{15} \mathrm{~N}$ and $\delta^{13} \mathrm{C}$ values of serum from captive otariids (northern fur seals Callorhinus ursinus) held for $6+$ mo on a constant diet were $1.1 \%$ higher and $0.7 \%$ lower, respectively, than those of the RBCs. In this study, the mean $\delta^{15} \mathrm{~N}$ values from serum from Steller sea lions were higher than those for RBCs in Regions 1, 3, and 4 by averages of $1.4,1.3$, and $0.8 \%$, respectively. The mean $\delta^{13} \mathrm{C}$ values from serum were lower than those for RBCs in Regions 1,3 , and 4 by $0.4,1.2$, and $1.5 \%$, respectively. These values are very near to that expected due to natural variations in biochemical construction between the 2 tissue types, indicating that sea lions do not undergo a significant change in trophic position between 6 and 9 mo of age (the approximate times represented by RBCs and serum).

In summary, estimation of foraging location and trophic level obtained via analyses of stable carbon and nitrogen isotopes collected from blood components of 9 mo old Steller sea lions in Alaska were consistent with regional differences in foraging ecology as predicted by analyses of juvenile and adult sea lion scat material from Sinclair \& Zeppelin (2002). The use of stable isotope analyses alone can be useful for researchers who are interested in collecting data from a specific individual or set of individuals rather than 
the more general estimates that are possible when collecting scats off haulout sites from unknown individuals. In addition, due to variation in protein and isotopic turnover times between tissues from the same individual, stable isotopes can be used to estimate trophic position and foraging region of sea lions over a variety of time periods. It is important to note that the successful application of $\delta^{13} \mathrm{C}$ values to the estimation of foraging location requires a rigorous understanding of the carbon isotope patterns that exist within the geographic regions of interest. Therefore, further studies on the spatial patterns of stable carbon isotopes in nature would contribute to their use as a valuable technique for tracking animals.

Acknowledgements. All Steller sea lion blood samples were collected under National Marine Fisheries Service (NMFS) permit number 782-1532. Thanks to P. Browne, K. Call, B. Fadely, K. Hughes, T. Spraker, and J. Sterling, who assisted with blood collection and processing, and to the USFWS, $\mathrm{K}$. Bell, and the crew of the MV 'Tiglax' for ship support. Thanks to T. Loughlin, E. Sinclair, R. Ream, and T. Gelatt for support, P. Raimondi for statistical assistance, and T. Maddox at the University of Georgia Institute of Ecology for isotope analyses. Thanks to L. Cornick, G. Duker, B. Fadely, T. Gelatt, J. Lee, S. Melin, A. Orr, L. Rea, T. Zeppelin, and 3 anonymous reviewers for comments that improved this manuscript.

\section{LITERATURE CITED}

Arim M, Naya DE (2003) Pinniped diets inferred from scats: analysis of biases in prey occurrence. Can J Zool 81:67-73

Burkhardt S, Riebesell U, Zondervan I (1999) Effects of growth rate, $\mathrm{CO}_{2}$ concentration, and cell size on the stable carbon isotope fractionation in marine phytoplankton. Geochim Cosmochim Acta 63:3729-3741

DeMaster DP, Trites AW, Clapham P, Mizroch S, Wade P, Small RJ, Ver Hoef J (2006) The sequential megafaunal collapse hypothesis: testing with existing data. Prog Oceanogr 68:327-340

Descolas-Gros C, Fontugne M (1990) Stable carbon isotope fractionation by marine phytoplankton during photosynthesis. Plant Cell Environ 13:207-218

Duggins DO, Simenstad CA, Estes JA (1989) Magnification of secondary production by kelp detritus in coastal marine ecosystems. Science 245:170-173

Fantle M, Dittel A, Schwalm S, Epifanio C, Fogel M (1999) A food web analysis of the juvenile blue crab, Callinectes sapidus, using stable isotopes in whole animals and individual amino acids. Oecologia 120:416-426

France RL (1995) Carbon-13 enrichment in benthic compared to planktonic algae: foodweb implications. Mar Ecol Prog Ser 124:307-312

Fritz L, Hinckley S (2005) A critical review of the regime shift - 'junk food' - nutritional stress hypothesis for the decline of the western stock of the Steller sea lion. Mar Mamm Sci 21:476-518

Gannes LZ, O'Brien DM, Martinez del Rio C (1997) Stable isotopes in animal ecology: assumptions, caveats, and a call for more laboratory experiments. Ecology 78:1271-1276

Hirons AC, Schell DM, Springer AM (1998) Isotope ratios in Steller sea lions, northern fur seals, and harbor seals of the Bering Sea and western Gulf of Alaska: trophic implica- tions. In: Schell D (ed) Testing conceptual models of marine mammal trophic dynamics using carbon and nitrogen stable isotope ratios, Vol OCS Study MMS98-0031. US Department of Interior, Minerals Management Service, Anchorage, AK, p 31-54

Hobson KA (1999) Tracing origins and migration of wildlife using stable isotopes: a review. Oecologia 120:314-326

Hobson KA (2005) Using stable isotopes to trace long-distance dispersal in birds and other taxa. Divers Distrib 11: $157-164$

Hobson KA, Gibbs H, Gloutney M (1997) Preservation of blood and tissue samples for stable-carbon and stablenitrogen isotope analysis. Can J Zool 75:1720-1723

Jenkins S, Partridge S, Stephenson T, Farley S, Robbins C (2001) Nitrogen and carbon isotope fractionation between mothers, neonates, and nursing offspring. Oecologia 129: $336-341$

Kelly JF (2000) Stable isotopes of carbon and nitrogen in the study of avian and mammalian trophic ecology. Can J Zool 78:1-27

Kurle CM (2002) Stable-isotope ratios of blood components from captive northern fur seals (Callorhinus ursinus) and their diet: applications for studying the foraging ecology of wild otariids. Can J Zool 80:902-909

Kurle CM, Worthy GAJ (2001) Stable isotope assessment of temporal and geographic differences in feeding ecology of northern fur seals (Callorhinus ursinus) and their prey. Oecologia 126:254-265

Kurle CM, Worthy GAJ (2002) Stable nitrogen and carbon isotope ratios in multiple tissues of the northern fur seal Callorhinus ursinus: implications for dietary and migratory reconstructions. Mar Ecol Prog Ser 236:289-300

Loughlin TR (1997) Using the phylogeographic method to identify Steller sea lion stocks. Molecular genetics of marine mammals. Spec Publ Soc Mar Mamm 3:159-171

Loughlin TR, York AE (2000) An accounting of the sources of Steller sea lion, Eumetopias jubatus, mortality. Mar Fish Rev 62:40-45

Loughlin TR, Sterling JT, Merrick RL, Sease JL, York AE (2003) Diving behavior of immature Steller sea lions (Eumetopias jubatus). Natn Mar Fish Serv Fish Bull NOAA 101:566-582

McConnaughey T, McRoy C (1979) Food-web structure and the fractionation of carbon isotopes in the Bering Sea. Mar Biol 53:257-262

Nakatsuka T, Handa N, Wada E, Wong C (1992) The dynamic changes of stable isotopic ratios of nitrogen and carbon in suspended and sedimented particulate organic matter during a phytoplankton bloom. J Mar Res 50:267-296

Nelson G (1970) The lipid composition of the blood of marine mammals. I. Young elephant seals (Mirounga augustirostris) and harp seals (Pagophilus groenlandicus). Comp Biochem Physiol 34:109-116

Nelson G (1971) The lipid composition of the blood of marine mammals. II. Atlantic bottlenose dolphins (Tursiops truncatus) and two species of seals (Halichoerus grypus and Phoca vitulina). Comp Biochem Physiol 40:423-432

Popp B, Laws E, Bidigare R, Dore J, Hanson K, Wakeham S (1998) Effect of phytoplankton cell geometry on carbon isotopic fractionation. Geochim Cosmochim Acta 62: $69-77$

Rau G, Mearns A, Young D, Olson R, Shafer H, Kaplan I (1983) Animal ${ }^{13} \mathrm{C} /{ }^{12} \mathrm{C}$ correlates with trophic level in pelagic food webs. Ecology 64:1314-1318

Raum-Suryan K, Rehberg M, Pendleton G, Pitcher K, Gelatt T (2004) Development of dispersal, movement patterns, and haul-out use by pup and juvenile Steller sea lions (Eume- 
topias jubatus) in Alaska. Mar Mamm Sci 20:823-850

Reisewitz SE (2002) Changes in Aleutian Island fish communities: a radiating trophic response to killer whale predation on sea otters? MSc thesis, University of California, Santa Cruz

Rubenstein DR, Hobson KA (2004) From birds to butterflies: animal movement patterns and stable isotopes. Trends Ecol Evol 19:256-263

Sease J, Taylor W, Loughlin TR, Pitcher K (2001) Aerial and land-based surveys of Steller sea lions (Eumetopias jubatus) in Alaska, June and July 1999 and 2000. NOAA Tech Memo NMFS-AFSC-71:122

Simenstad CA, Duggins DO, Quay P (1993) High turnover of inorganic carbon in kelp habitats as a cause of $\delta^{13} \mathrm{C}$ variability in marine food webs. Mar Biol 116:147-160

Sinclair ES, Zeppelin TK (2002) Seasonal and spatial differences in diet in the western stock of Steller sea lions (Eumetopias jubatus). J Mammal 83:973-990

Springer AM, Estes JA, van Vliet GB, Williams TM, Doak DF,

Editorial responsibility: Otto Kinne (Editor-in-Chief), Oldendorf/Luhe, Germany
Danner EM, Forney KA, Pfister B (2003) Sequential megafaunal collapse in the North Pacific Ocean: an ongoing legacy of industrial whaling? Proc Natl Acad Sci USA 100:12223-12228

Tortell P, Rau G, Morel F (2000) Inorganic carbon acquisition in coastal Pacific phytoplankton communities. Limnol Oceanogr 45:1485-1500

Trites AW, Porter B (2002) Attendance patterns of Steller sea lions (Eumetopias jubatus) and their young during winter. J Zool 256:547-556

Vanderklift MA, Ponsard S (2003) Sources of variation in consumer-diet $\delta^{15} \mathrm{~N}$ enrichment: a meta-analysis. Oecologia 136:169-182

Zeppelin TK, Tollit DJ, Call KA, Orchard TJ, Gudmundson C (2004) Sizes of walleye pollock (Theragra chalcogramma) and Atka mackerel (Pleurogrammus monopterygius) consumed by the western stock of Steller sea lions (Eumetopias jubatus) in Alaska from 1998-2000. Natn Mar Fish Serv Fish Bull NOAA 102:509-521

Submitted: September 15, 2006; Accepted: December 22, 2006 Proofs received from author(s): July 6, 2007 